\title{
Environmental impact of fertilizer use and slow release of mineral nutrients as a response to this challenge
}

\author{
Krzysztof Lubkowski \\ Institute of Chemical and Environment Engineering, West Pomeranian University of Technology, Szczecin, Putaskiego 10, \\ 70-322 Szczecin, Poland \\ "Corresponding author: e-mail: krzysztof.lubkowski@zut.edu.pl
}

\begin{abstract}
This paper presents the most important issues relating to the influence of mineral fertilizers on both the natural environment and human and animal health. The physiological, environmental and economic impact of fertilizer production and application, resulted from a low assimilation of mineral components by crops, has been described. The research on the development and production of a large and diverse group of materials with slow-release properties that can increase the effectiveness of nutrient uptake, alleviate the negative influence of fertilizers on the environment and reduce labor and energy consumption associated with the use of conventional fertilizers, has been reviewed.
\end{abstract}

Keywords: nutrient use efficiency, slow-release fertilizers.

\section{INTRODUCTION}

Agriculture is a sector of the economy that plays a very crucial role in the world as a food producer and as a place of employment for millions of people. Growing from the end of XVIII century intensification of agricultural production was possible due to the use of high yielding varieties, irrigation and mechanization as well as to the soil feeding with mineral fertilizers and the crop protection with pesticides ${ }^{1}$. Consumption of these agrochemicals essentially increased during last fifty years, resulted not only in the growth of agricultural production but also in the pollution of natural environment.

Mineral fertilizers are some of the most important products of agricultural industry. While providing nutrients to crops, they increase their growth and at the same time they play an important role in regulating both $\mathrm{pH}$ and fertility of the soil. Production and consumption of mineral fertilizers have risen along with an increase of human population and a need for increased food production $^{2,3}$. Between 1961 and 2001 the human population of the world doubled from $3.1 \mathrm{mld}$ to almost 6.2 mld persons, whereas grain production, meat production and fertilizer consumption increased in the same period by the factor 1.4, 2.3 and 6.0, respectively ${ }^{2}$. According to The United Nations predictions ${ }^{4}$, global population is expected to reach approximately 7.3, 8.1 and $9.6 \mathrm{mld}$ in 2015, 2025 and 2050, respectively.

Global consumption of mineral fertilizers with a shortand medium-term forecast for world fertilizer demand is presented in Table 1. Fertilizer consumption has systematically increased in recent years, with a slight decrease in consumption occurring in 2008/2009 due to the crisis in the banking system.

An increased production of fertilizers and soil fertilization contrasts with a relatively low nutrient assimilation by crops. The efficiency of mineral components assimilation (NUE - nutrient use efficiency) depends on complex interactions in crops' root systems, soil microorganisms, chemical reactions taking place in soil and processes leading to adverse elimination of them from soil. Most fertilizers are easily soluble in water. During their application in water a soil solution with a given mineral compounds concentration is created. Minerals are absorbed from soil by crops' root systems mainly through the mass transfer. In order to make this assimilation more effective, fertilizers should be delivered no farther than 3-4 cm from the root system of a plant. If the amount of delivered minerals exceeds the plants intake capability, processes leading to a decrease of their concentration are activated. These processes include both physical and chemical processes (rinsing out, leaching, volatilization, immobilization, replacement, precipitation, hydrolysis) and also microbiological conversions. An uptake of fertilizer nitrogen by plants is approximately $50 \%$ on average ${ }^{2,6-8}$, with the lowest values $(30-35 \%)$ in rice production ${ }^{2,9}$ and the highest ones in intensive maize production ${ }^{2}$. It is estimated that assimilation of phosphorous and potassium reaches $10-25 \%$ and $50-60 \%$, respectively ${ }^{10-13}$.

Table 1. Global consumption of mineral fertilizers (Mt nutrients) ${ }^{5}$

\begin{tabular}{|c|c|c|c|c|}
\hline Years & $\mathrm{N}$ & $\mathrm{P}_{2} \mathrm{O}_{5}$ & $\mathrm{~K}_{2} \mathrm{O}$ & Total \\
\hline $2000 / 2001$ & 80.8 & 32.4 & 22.2 & 135.4 \\
\hline $2006 / 2007$ & 97.4 & 38.1 & 26.9 & 162.4 \\
\hline $2007 / 2008$ & 100.5 & 38.4 & 28.9 & 167.8 \\
\hline $2009 / 2010$ & 102.2 & 37.6 & 23.7 & 163.5 \\
\hline $2010 / 2011$ & 104.1 & 40.6 & 27.5 & 172.2 \\
\hline $2011 / 2012$ & 107.8 & 40.6 & 27.7 & 176.1 \\
\hline $2012 / 2013$ & 108.1 & 41.6 & 29.1 & 178.8 \\
\hline $2013 / 2014$ & 110.4 & 40.3 & 30.2 & 180.9 \\
\hline $2014 / 2015(\mathrm{e})$ & 111.8 & 41.3 & 31.5 & 184.6 \\
\hline $2015 / 2016$ (f) & 112.9 & 41.8 & 31.8 & 186.5 \\
\hline $2019 / 2020(f)$ & 119.2 & 45.7 & 35.3 & 200.2 \\
\hline
\end{tabular}

(e): estimation; (f): forecast. 


\section{INFLUENCE OF MINERAL FERTILIZERS ON THE NATURAL ENVIRONMENT}

Low effectiveness of nutrients assimilation causes serious problems in view of environmental protection ${ }^{2,6,14-16}$. It leads to the environmental dispersion of excess biogenic compounds that were not completely used up in the plant production. Thus the migration of these compounds in the global aspect begins. In many ecosystems the consequences of that dispersion are comparable with geological and geochemical processes lasting millions years. Mineral fertilizer compounds migrate from soil to water ecosystems along with the areal run-offs and as a result of erosion and rinsing out. It is the reason of accelerated contamination and eutrophication of surface and sea waters ${ }^{\mathbf{1 7}, \mathbf{1 8}}$. The pace increase of this natural processes brings about severe deterioration of terrestrial and aquatic ecosystems, excessive phytoplankton growth, and as a consequence overgrowth and shallowing of water reservoirs. It was reported ${ }^{19}$ that $50-70 \%$ of the pollution with nitrogen compounds comes from agricultural areas water outflows. Thus the limitation of these compounds dispersion should be searched in the agriculture.

Low effectiveness of nutrients (mainly nitrogen) assimilation causes serious problems also in view of human and animal health ${ }^{2,6,20}$. Because of the soil microorganisms mineral nitrogen undergoes transformation to nitrates easily soluble in soil. Nitrates are later leached from soil to ground and surface waters. The biggest potential danger of nitrates leaching can be met on the light soils. An increased concentration of nitrates in waters can be connected with methemoglobina related diseases found in children ("baby blue syndrome") 2, 21, 22 and in ruminant animals ${ }^{2,21}$. Excessive amounts of reactive nitrogen may be also linked to some cancers, respiratory ailments and cardiac diseases ${ }^{\mathbf{2 0}}$ as well as with other disorders like goitre and birth defects ${ }^{\mathbf{1 1}}$. Excessive nitrogen was also pointed out to have an influence on allergy and the dynamics of some vector-borne diseases like West Nile virus, malaria, and cholera ${ }^{20}$. The concentration of nitrites and nitrosamines (derivatives of nitrates), was also associated with digestive system diseases ${ }^{23}$. Increased level of nitrates and nitrites in crops which are the staple food for people and animals can negatively affect their health ${ }^{11}$. It was pointed out that excessive amounts of fertilizers change the degree of salinity and $\mathrm{pH}$ of the soil, leading to its gradual degradation ${ }^{6}$. Urea and ammonium salt, used as mineral fertilizers are potential sources of ammonia. Its migration into adjacent ecosystems disturbs or destroys vegetation of other plants ${ }^{\mathbf{6}, 22}$. A part of ammonia, after conversion into nitric acid, combines with sulphuric acid and in the form of acid rains badly affects vegetation and leads to erosion and soil depletion ${ }^{6,11,22}$. As a result of denitrification processes taking place in soil both nitrogen monoxide (I) and nitric oxide (II) are created. They are responsible for the depletion of the ozone layer, subjecting people to the exposure of ultraviolet radiation ${ }^{2,11,15,24}$. It is worth noting that an excessive concentration of mineral constituents and too high osmotic pressure of soil solution lead to a decrease of water content, withering and an abnormal crop growth.
Phosphorous balances in agriculture in many cases are positive ${ }^{25,26}$. It means that intensive fertilization with phosphorous (frequently even multiple compared to the amounts of that component taken-up by the plants) results in accumulation of this element in soil. Main amounts of phosphorous accumulate in arable lands and in lands around the people settlements. Ammonium phosphates and superphosphates containing calcium phosphate $\mathrm{Ca}\left(\mathrm{H}_{2} \mathrm{PO}_{4}\right)_{2}$, introduced into the soil, are the compounds easily soluble in water. They readily relocate in the acid medium, and they may be used up by plants as a source of phosphorous. In the basic medium, phosphorous compounds are strongly bound in the phosphorous-retarded reactions between soluble phosphates and aluminum, iron, manganese and calcium ions. These reactions (described as P sorption, adsorption, retention, fixation, precipitation or immobilization) lead to the generation of insoluble salts, that are not leachable and do not move on into the soil profile. Thus they significantly limit availability of phosphorous for plants ${ }^{27,28}$. That situation creates requirements of regular providing the cultivated plants with phosphate fertilizers. On the other hand, excessive amounts of phosphorous (in the form of phosphates) in the terrestrial and in the aquatic environment have a detrimental effect on water quality resulting from accelerated eutrophication ${ }^{25}$. Additionally, phosphate fertilizers contain natural trace contaminants (cadmium, chromium, lead, uranium and radium) which can accumulate in fertilized soils ${ }^{25}, \mathbf{2 9}$.

The presence in the European Union requires even much more critical insight into the ecological consequences of the agriculture chemicalization. Directive 2000/60/ EC of the European Parliament and of the Council of 23 October 2000, so called The Water Framework Directive $(\mathrm{WFD})^{\mathbf{3 0}}$ establishes a framework for Community action in the field of water policy. It is the result of many years of work of the European Union Member States aiming at effective protection of water resources by introducing common water policy based on transparent, effective and uniform legislative framework. WFD obliges Member States to rational use and protection of water resources according to the principle of sustainable development using the appropriate repeating planning cycle. The superior objective of the Water Framework Directive is to achieve the good status of water by 2015 .

Improvement in the water quality is strictly connected with limitation of pollution sources. The problem of water protection towards agriculture-based nitrogen pollution is dealt with the Directive 91/676/EWG of the European Parliament of 12 December 1991, so called the Nitrates Directive ${ }^{31}$. The Nitrates Directive aims to protect water quality across Europe by preventing nitrates from agricultural sources polluting ground and surface waters and by promoting the use of good farming practices. The Nitrates Directive forms an integral part of the Water Framework Directive and is one of the key instruments in the protection of waters against agricultural pressures. In accordance with this Directive each Member State is obliged to put in place a Nitrates Action Programme and to review and revise, if necessary, their action programme at least every four years. Article 10 of the Directive obliges Member States to report every four years to the European Commission on the imple- 
mentation of the Directive in their country. The Nitrates Directive requires Member States to monitor surface waters and groundwater for nitrate pollution against a maximum limit of $50 \mathrm{mg} \mathrm{NO} / 1$. Where this level of pollution is reached, or trends indicate that it could be reached if Action Programmes under the Directive are not established, land draining into the affected waters (and which contribute to pollution) must be designated as a Nitrate Vulnerable Zone (NVZ).

The problem of ground and surface waters protection towards pollution with phosphorous and limitation of this element losses from the farmland sources will be the subject of the Phosphates Directive, being elaborated at the moment.

The production of mineral fertilizers is in itself a risky factor, during which hazardous substances are released into the environment ${ }^{15}$. These substances include sulfur oxides, nitric oxides, fluorine compounds and dust.

Little assimilability of mineral components has unfavourable effects also in the economic aspect of the issue. Minerals losses, spent energy and human work effort negatively affect the total economic balance of the whole agrochemical production process ${ }^{32,33}$. Global production of mineral fertilizer in 2014 was approximately $200 \mathrm{Mt} / \mathrm{year}{ }^{5}$. Considering the assimilation of nutrients at a safe level of $60-70 \%$, annual losses of nutrients can be estimated at $60-80 \mathrm{Mt}$, which corresponds to the financial losses of 18-24 mld USD. At the same time, a consumption of non-renewable sources of energy (such as natural gas) used for production of mineral fertilizers, should also be pointed out.

In the light of the aforementioned prerequisites, the tasks of paramount importance are to increase the effectiveness of nutrients assimilation and to decrease material losses, while at the same time to limit the amount of fertilizers' waste material produced by the industry. Improvements in nutrient use efficiency resulting from developments in fertilizer production and utilization have been thoroughly discussed and summarized elsewhere ${ }^{6,13,34}$.

Increase in the effectiveness of nutrient assimilation can be achieved through intensified activity in the following areas:

- production of liquid fertilizers in both solution and suspension forms (elimination of drying and granulation stages of the process),

- production of stabilized fertilizers (with nitrification or urease inhibitors),

- production of urea supergranules or urea supergranules containing $\mathrm{P}$ and $\mathrm{K}$ nutrients for a deep placement,

- developing, producing and applying fertilizers with a delayed release of mineral nutrients.

\section{FERTILIZERS WITH SLOW RELEASE OF NUTRIENTS}

Fertilizers with a delayed release of mineral nutrients, so-called "intelligent fertilizers", release mineral components according to the nutrient requirements of the plants ${ }^{10-12}$. Examples of such materials are slow-release fertilizers (SRF) and controlled-release fertilizers (CRF) and they are produced in order to gradually release mi- neral components, simultaneously ensuring the proper plant nutrition.

The economic, environmental and physiological advantages related to the soil application of slow- and/or controlled-release fertilizers were discussed thoroughly elsewhere ${ }^{10-12,15}$. It should be recalled here merely the most important findings associated to these issues. Nutrients uptake by plants in their vegetation cycle has a sigmoidal character ${ }^{11,15}$. An application of SRF/CRF which release their nutrients in a way better fitting plants' requirements ensures an improved effectiveness of fertilization through minimizing losses between application and absorption. At the same time using SRF/CRF allows to reduce negative influence fertilizers have on the environment largely due to high solubility of nitrogen compounds which are left unused. In conventional fertilizing (e.g. with urea) nutrients release lasts 30-60 days, which given a 100-120 day long crops growth cycle means that a fertilizers must be applied 2 or 3 times. SRF/CRF release their nutrients slowly and gradually during all vegetation season and consequently need to be applied once only, which greatly reduces both time and energy consumption. A better and more efficient use of nutrients can lead both to a reduction of waste material produced by the fertilizers industry and to a reduction in natural gas and other resources consumption. The application of SRF/CRF increases also crops' yield.

According to the Association of American Plant Food Control Officials (AAPFCO) ${ }^{35}$ slow-release fertilizers (SRF) are chemically or biologically decomposed materials with a high molecular weight, complex structure and small solubility in water, whereas controlled-release fertilizers (CRF) are materials in case of which the release of mineral components takes place through a polymer layer or a membrane.

Among the slow-release fertilizers (SRF) of commercial importance two groups of materials can be distinguished:

- products of reaction between urea and aldehydes: urea-formaldehyde products $\left(U F^{\mathrm{TM}}\right)$, isobutylidene diurea $\left(I B D U^{\mathrm{TM}}\right)$, crotonylidene diurea $\left(C D U^{\mathrm{TM}}\right)$, glycoluril (acetylene diurea),

- other synthetic organic products like oxamides, guanylurea sulphate and melamine.

Urea and formaldehyde condensation products have been first discovered and developed by the German companies in the twenties of the twentieth century ${ }^{36}$. The prime patent related to the application of urea-formaldehyde condensation products as fertilizer has been registered in USA in $1947^{37}$, and it was commercialized in the early fifties of the twentieth century. Presently a few types of urea-formaldehyde products (described shortly below) are manufactured and marketed in the form of concentrates, suspensions and solutions.

The condensation reaction of urea with formaldehyde results in a mixture containing short-chain and long-chain polymers of methylene urea and some amounts of unreacted urea. A part of urea-formaldehyde condensation products, containing at least $30 \%$ of total nitrogen is referred to as cold water soluble nitrogen (CWSN). Apart from free, unreacted urea (max. 55\%), it comprises the following short-chain components: methylol ureas, methylolurea ethers, methylene diurea (MDU) and dimethylene triurea (DMTU). Another part of 
urea-formaldehyde condensation products, referred to as cold water insoluble nitrogen (CWIN), contains various percentage of total nitrogen, largely in water insoluble but slowly available form. It comprises the following medium molecular weight polymers with longer chains: ureaform (at least 35\% of total nitrogen), trimethylene tetraurea (TMTU) and tetramethylene pentaurea (TMPU) with the content of total nitrogen less than $35 \%$. The last part of urea-formaldehyde condensation products is referred to as hot water insoluble nitrogen (HWIN), with pentamethylene hexaurea (PMHU) as an example of heavy, long chain polymer.

As a result of the reaction between urea, formaldehyde and ammonia another slow-release $\mathrm{N}$ fertilizer, urea-triazone solution, is produced ${ }^{38}$. Urea-triazone is a heterocyclic, patented compound $\left(\mathrm{C}_{3} \mathrm{H}_{7} \mathrm{~N}_{3} \mathrm{O}-1,3,5\right.$ triazin-2-one, tetrahydro-s-triazone), containing $28 \%$ of total nitrogen, used for foliar and soil application.

After application in soil, urea-formaldehyde condensation products are subjected to microbial decomposition $^{39,}{ }^{40}$. The rate of nitrogen release from these compounds depends upon soil properties and polymer chain length: the longer the polymer the worse solubility and plants availability of nitrogen ${ }^{41}$.

Isobutylidene diurea (IBDU, 1,1-diureido isobutane) is the condensation product of isobutyraldehyde and urea with the total nitrogen content of min. $30 \%{ }^{42}$. It is a crystalline, white solid with low water solubility - nitrogen release from it depends upon the rate of hydrolysis and is not microbe-dependent ${ }^{43}$.

Crotonylidene diurea (CDU, 2-oxo-4-methyl-6-ureidohexahydropyrimidine) is a ring-structured product with the total nitrogen content of min. $32 \%$, manufactured in the condensation reaction of acetaldehyde and urea in the presence of an acid as a catalyst ${ }^{44}$, however initially it was produced from crotonaldehyde and urea ${ }^{45}$. The release of nitrogen from that compound is a result of hydrolysis and microbial degradation ${ }^{15}$.

Glycoluril (acetylene diurea, tetrahydroimidazo[4,5-d] imidazole-2,5(1H,3H)-dione) is synthesized by means of condensation reaction from glyoxal and urea in the presence of an acid as a catalyst ${ }^{46}$. It has comparatively high nitrogen content and very good plant tolerance.

Oxamide (ethanediamide, oxalic acid diamide) is a white, crystalline solid of the formula $\left(\mathrm{CONH}_{2}\right)_{2}$ which contains $28-32 \%$ of nitrogen. Due to low solubility in water it is used as a substitute for urea in fertilizers ${ }^{47}$.

Melamine (2,4,6-triamino-1,3,5-triazine) means a fertilizer that is a sparingly soluble organic compound of formula $\mathrm{C}_{3} \mathrm{H}_{6} \mathrm{~N}_{6}$ which contains at least $66 \%$ of nitrogen ${ }^{48}$. Despite the high nitrogen content its agricultural importance is quite questionable because of the production price and very slow nitrogen mineralization process.

Guanylurea sulphate (carbamylguanidine sulphate $\left.\left(\mathrm{C}_{2} \mathrm{H}_{6} \mathrm{ON}_{4}\right)_{2} \cdot \mathrm{H}_{2} \mathrm{SO}_{4} \cdot 2 \mathrm{H}_{2} \mathrm{O}\right)$ is a white powder, soluble in water which contains $33 \%$ of nitrogen ${ }^{49}$.

Another group of materials, with properties similar to slow release fertilizers, are matrix-based fertilizers, where active mineral components are dispersed in a matrix, i.e. they are mixed with miscellaneous polymeric materials that lower their dissolution rate. The rate of nutrients release from matrix system is affected by two processes: diffusion in pores and canals of a matrix and physical and biochemical degradation of a matrix. The first study on the matrix system based on natural rubber was published in $1987^{\mathbf{5 0}}$ and it was followed by the series of papers ${ }^{51-55}$ describing preparation and characterization of a matrix of natural rubber encapsulated urea fertilizer, obtained with the use of a two roll rubber mixer and a special "split-feeding" mixing technique. Mixtures of natural rubber and urea with an addition of fillers (carboxymethyl cellulose, wheat straw or clay) were also examined as slow release fertilizers ${ }^{56}$. Natural rubber and styrene-butadiene rubber were used as binding matrices controlling the release of phosphates from dihydrogen potassium phosphate $^{57}$ and nitrogen from ammonium nitrate ${ }^{58}$, respectively. Both natural rubber and styrene-butadiene rubber were also used as binding matrices to control the release of micronutrient $\mathrm{Zn}$ from zinc sulphate ${ }^{59}$. Additionally, styrene-butadiene rubber latex emulsions were mixed with the complex, multicomponent NPK fertilizer and the usefulness of the resulting matrix material has been evaluated biologically using sandy calcareous soil ${ }^{60}$. To lower the release rate of micronutrient zinc from zinc fertilizer a thermoplastic matrices in the form of pellets were produced by extruding a mixture of zinc salts and inert polymer material (based on low density polyethylene, poly(ethylene vinyl acetate) copolymer, and blends of them $)^{61-63}$. A foliar, slow release fertilizer has been also developed ${ }^{64}$ in the form of a "water in oil" emulsion, using a residual product resulting from the edible oils refining.

The usefulness of the above presented matrix-based slow released fertilizers is very limited in practice, because in comparison with commercial products their properties are rather poor and the dissolution rate of nutrients from them is too fast ${ }^{15}$. Nonetheless, the matrix system's great advantage is its simple construction, and the future commercial application of this type of fertilizers would be possible provided that appropriate and inexpensive polymer material is used.

Another group of materials, that can be classified as slow release fertilizers are inorganic low-solubility compounds. This type of materials may be also treated as matrix-based formulations, however in that case the matrices are made of inorganic substances or compounds. This group comprises:

- metal ammonium phosphates, metal potassium phosphates and mixtures thereof,

- other low solubility phosphates, including thermal phosphates and zeolites.

Metal ammonium or potassium phosphates are compounds of general formula $\mathrm{MeNH}_{4} \mathrm{PO}_{4} \cdot \mathrm{xH}_{2} \mathrm{O}$ or $\mathrm{MeKPO}_{4} \cdot \mathrm{xH}_{2} \mathrm{O}$, respectively, with $\mathrm{Mg}, \mathrm{Fe}, \mathrm{Zn}$ or $\mathrm{Mn}$ as a divalent Me cation. A classical example of this type of compounds is struvite, a crystalline substance with equal molar concentration of magnesium, ammonium and phosphorous $\left(\mathrm{MgNH}_{4} \mathrm{PO}_{4} \cdot 6 \mathrm{H}_{2} \mathrm{O}\right)$. Struvite contains $10 \%$ of $\mathrm{N}$ and $41 \%$ of $\mathrm{P}_{2} \mathrm{O}_{5}$, it is sparingly soluble in neutral and alkaline conditions and readily soluble in acids. An interest in struvite application as a slow release fertilizer is dated from the seventies of the XX century ${ }^{65}$. A good source of struvite, pointed out as an effective alternative of phosphate rock, would be wastewaters which contains a high amount of phosphorus and nitrogen ${ }^{66-68}$. Recovery of phosphorus and nitrogen from wastewaters of various 
types (livestock, municipal, industrial, agro-industrial and other miscellaneous wastewaters) through struvite crystallization has been recently thoroughly reviewed ${ }^{69}$. The rate of nutrient dissolution from struvite-based fertilizers depends upon particle size, soil moisture content, $\mathrm{pH}$ and temperature ${ }^{\mathbf{1 5}}$. Despite the commercial usefulness of struvite-based fertilizers is quite promising, their application is rather limited at the moment.

In the context of magnesium/potassium ammonium phosphates it is worth mentioning that these compounds were also prepared with the use of a mechanochemical processes $^{70}$. The starting materials, ammonium dihydrogen phosphate or potassium dihydrogen phosphate were milled with magnesium hydroxide at a molar ratio 1:1 in a planetary ball mill. Additionally, it was pointed out that the mechanochemical processes could be developed to prepare other compounds with possible application as slow-release fertilizers, like magnesium aluminum nitra$\mathrm{te}^{71}$, the composites of potassium/ammonium phosphate with alumina ${ }^{72}$ and kaolin $^{73}$ or potassium-silicon-calcium compouds $^{74}$.

Among low solubility phosphate fertilizers of commercial importance the following materials can be specified: phosphate rocks (PRs) for direct application, partially acidulated phosphate rocks (PAPRs) and thermal phosphates. The use of phosphate rock and partially acidulated phosphate rock fertilizers as phosphorus sources for plants and their reactions in soils have been intensively investigated and the results of these studies have been

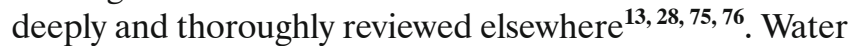
insoluble phosphate rocks are the primary material from which all the phosphate fertilizers are produced. Apatite (calcium phosphate), crandallite (aluminium phosphate) and millisite (iron and aluminium phosphate) are the main mineral deposits of phosphate rocks occurring in nature, with apatite as the most abundant ${ }^{75}$. Phosphate rocks can be of igneous (volcanic) origin or can be sedimentary ores. Igneous rocks (South Africa, Russia, Canada) show higher $\mathrm{P}_{2} \mathrm{O}_{5}$ content (37-39\%), but these rocks are generally not available. Sedimentary ores (USA, Morocco, Algeria) possess higher amounts of calcium compounds, thus lowering the $\mathrm{P}_{2} \mathrm{O}_{5}$ content $(<37 \%)$. Both types of ore are of the apatite group, of which the most commonly encountered variants are: fluorapatite $\mathrm{Ca}_{10}\left(\mathrm{PO}_{4}\right)_{6} \mathrm{~F}_{2}$ and hydroxyapatite $\mathrm{Ca}_{10}\left(\mathrm{PO}_{4}\right)_{6}(\mathrm{OH})_{\mathrm{x}} \mathrm{F}_{2-\mathrm{x}}$, predominant in igneous phosphate rocks, and francolite $\mathrm{Ca}_{10}\left(\mathrm{PO}_{4}\right)_{6-\mathrm{x}}\left(\mathrm{CO}_{3}\right)_{\mathrm{x}}(\mathrm{F}, \mathrm{OH})_{2+\mathrm{x}}$, predominant in sedimentary phosphate rocks. It has been found that "reactivity" of phosphate rocks, their plant availability and potential agronomic effectiveness as a phosphorus source depends and increases with the degree of carbonate substitution of phosphate in the apatite structure ${ }^{75}$.

Treatment of phosphate rocks with mineral acids (sulfuric, phosphoric and nitric) results in complete or partial dissolution of the ore. As a result of complete decomposition of phosphate rocks water soluble phosphate fertilizers (SSP - single superphosphate, TSP - triple superphosphate, MAP - monoammonium phosphate, DAP - diammonium phosphate and nitrophosphate) are formed. Partially acidulated phosphate rock (PAPR) fertilizers are manufactured by decomposition of phosphate rocks with smaller than stoichiometric amounts of acids. They are also produced by mixing water soluble phosphate fertilizers with "reactive" phosphate rocks. "Reactive" phosphate rocks and partially acidulated phosphate rocks are sparingly soluble in water and they proved to be cost-effective alternative as a phosphorus source for plants ${ }^{75}$. Quite recently the studies on the PAPR fertilizers manufacture and application have been also conducted in Poland ${ }^{77,78}$.

Thermal phosphates with slow-release properties are grouped into fused and calcined phosphates and are commercially manufactured by high temperature treatment of phosphate rock in the presence or absence of silica ${ }^{75,79}$. Fused magnesium phosphate (FMP), the classical example of fused phosphates, is produced at temperatures of $1300-1500^{\circ} \mathrm{C}$, where the fusion of phosphate rock with magnesium silicate (olivine or serpentine) takes place $^{\mathbf{7 5}, \mathbf{8 0}}$. Among the calcined phosphates, Rhenania and defluorinated phosphates are the most important. To obtain Rhenania phosphate, phosphate rock is calcined with sodium carbonate and silica at $1200^{\circ} \mathrm{C}$, whereas defluorinated phosphates (silicophosphates) are produced by the calcination of phosphate rock with silica at a similar temperature, but in the presence of steam ${ }^{75}$.

It should be kept in mind that the fertilizers manufactured from the phosphate rocks may be the source of natural radioactivity ${ }^{\mathbf{8 1 - 8 4}}$. Due to the use of the phosphate fertilizers significant amounts of uranium, radium and radium decay products are redistributed throughout the environment. It can be the reason of potential radiological impacts resulting from direct exposure, surface run-off, inhalation and ingestion of foods grown with fertilizers. Additionally, waste phosphogypsum piles, a by-product of fertilizer production, are also a significant source of radon emissions to air.

A phosphate rock is not the only substance that can be thermally treated to obtain materials with slow-release properties. This group contains also glasses or glass-ceramic materials, modified fly ashes and modified blast furnace slags. It was found in the series of papers ${ }^{\mathbf{8 5 - 8 8}}$ that glasses of the $\mathrm{P}_{2} \mathrm{O}_{5}-\mathrm{CaO}-\mathrm{SiO}_{2}-\mathrm{K}_{2} \mathrm{O}-\mathrm{MgO}$ system with various microelements ( $\mathrm{Fe}, \mathrm{Mo}, \mathrm{Zn}, \mathrm{B}, \mathrm{Mn}, \mathrm{Cu}$ ) can be prepared by melting of phosphate rocks (apatite) with magnesium silicate (serpentine), $\mathrm{K}_{2} \mathrm{CO}_{3}$ and mixtures of metal oxides. Biochemical activity of micronutrient-modified potassium-silicate-phosphate glasses depends on the nature and the number of components forming the glassy framework and on the thermal stability of the glasses ${ }^{\mathbf{8 5}}$. Chemical reactivity of the glasses in the soil environment comprises: i) gradual decomposition of the glass structure and leaching out the glass components, ii) formation of a layer of metastable solid products on the glass surface and gradual leaching out the surface layer components ${ }^{\mathbf{8 6}}$. Calcium phosphate glass-ceramic materials in the $\mathrm{P}_{2} \mathrm{O}_{5}-\mathrm{CaO}-\mathrm{SiO}_{2}-\mathrm{K}_{2} \mathrm{O}$ and $\mathrm{P}_{2} \mathrm{O}_{5}-\mathrm{CaO}-\mathrm{Na}_{2} \mathrm{O}$ systems were also prepared by the thermal treatment of various raw materials and they were fully examined and described in the literature ${ }^{89}$. As to the fly ashes, it was shown ${ }^{90}$ that nitrogen could be fixed into fly ashes through carbothermal reduction and nitridation reaction, and this new modified material has the potential to be a source of slow release nitrogen fertilizer. Blast furnace slags were in turn melted with mixtures of $\mathrm{K}_{2} \mathrm{CO}_{3}$ and $\mathrm{H}_{3} \mathrm{PO}_{4}$ in various proportions ${ }^{91}$. The resulted molten, modified slag, containing silicates and phosphates, proved to be an 
effective slow-release fertilizer. It should be mentioned here that fused potassium silicate (FPS), produced from steel-making slag, with the major component found to be a single phase compound $\left(\mathrm{K}_{2} \mathrm{Ca}_{2} \mathrm{Si}_{2} \mathrm{O}_{7}\right)$, have also received considerable attention as slow-release potassium fertilizers beneficial for crops ${ }^{22}$.

The materials with slow-release properties, resulted from the thermal treatment, require high energy input for calcination or fusion ${ }^{75}$. The energy cost has made these materials too expensive for broaden commercial utilization, and merely a few of them are manufactured on a larger scale. Nonetheless, they remain very interesting and attractive from the scientific point of view.

The agronomic effectiveness of mineral fertilizers can be also improved with the use of zeolites ${ }^{\mathbf{9 3}, 94}$. With external cation exchange capacity, ability to bind even big molecules and the unique feature of inorganic and organic salt occlusion, zeolites could be potential carriers of slow-release fertilizers. The mixtures of fertilizers and zeolites proved to provide a slow and sustained nutrient release with the rate of release controlled by the fertilizer to zeolite ratio $^{75}$. Nevertheless, such mixtures are too expensive and they are of no commercial use presently.

The last group of new slow-releasing fertilizer compounds have been developed on the basis of a short-chain and long-chain polyphosphate framework. In the series of papers ${ }^{95-99}$ the preparation and characterization of polyphosphate-based micronutrient fertilizers containing zinc, copper, iron, iron-manganese and molybdenum compounds have been described. Polyphosphate-based micronutrient fertilizers were also obtained as a result of condensation reaction of potassium dihydrogen phosphate and ammonium dihydrogen phosphate with various mole ratios ${ }^{\mathbf{1 0 0}}$. Prepared materials proved to have good slow-release properties and high bioavailability of the micronutrients, however they seem to be of no agroeconomic importance at the moment.

\section{CONCLUSIONS}

Slow-release fertilizers are quite numerous and diverse group of materials that may improve the effectiveness of fertilization, mitigate the negative impact of fertilizers on the environment and reduce labour and energy consumption connected with the application of conventional fertilizers. Slow-release fertilizers comprises the materials with complex structure and small solubility in water like urea-formaldehyde products, various synthetic organic products, matrix-based formulations, with the nutrients dispersed in the polymeric or inorganic matrices and polyphosphate-based micronutrient fertilizers. Some of them are of real commercial importance (for example urea-formaldehyde products) and from this point of view they seem to be an excellent response to the challenges of environmental protection. Whereas detailed discussion on the commercial importance of slow-release fertilizers are not addressed in the current work, that issue, with quantitative analysis and market shares included, will be the topic of the future paper.

\section{LITERATURE CITED}

1. Zapata, F. (2008). Introduction to nitrogen management in agricultural systems. In: Guide. Nitr. Managem. Agric. Syst., Vienna: IAEA.

2. Mosier, A.R., Syers, J.K. \& Freney, J.R. (2004). Agriculture and the nitrogen cycle: assessing the impacts of fertilizer use on food production and the environment, St. Louis, MI: Island Press.

3. Brown, L.R. (1999). Feeding nine billion. In L.R. Brown, C. Flavin, H. French (Eds.), State of the world: A Worldwatch Institute report on progress toward a sustainable society, New York: W.W. Norton \& Company.

4. United Nations, Department of Economic and Social Affairs, Population Division, (2013). World Population Prospects: The 2012 Revision, DVD Edition.

5. International Fertilizer Industry Association, Statistics, Market Outlooks; http://www.fertilizer.org/MarketOutlooks. html (accessed Aug 26, 2015).

6. van Cleemput, O., Zapata, F. \& Vanlauwe, B. (2008). Use of tracer technology in mineral fertilizer management. In: Guide. Nitr. Managem. Agric. Syst., Vienna: IAEA.

7. Dobermann, A. (2005). Nitrogen use efficiency - state of the art. In: Proceedings of the IFA International Workshop on Enhanced-Efficiency Fertilizers, Frankfurt: IFA.

8. Smil, V.A. (1999). Nitrogen in crop production: An account of global flows. Global Biogeochem. Cycl., 3, 647-662. DOI: 10.1029/1999GB900015.

9. Fan, X., Li, F., Liu, F. \& Kumar, D. (2004). Fertilization with a new type of coated urea: Evaluation for nitrogen efficiency and yield in winter wheat. J. Plant Nutr., 27, 853-865. DOI: 10.1081/PLN-120030675.

10. Hauck, R.D. (1985). Slow release and bio-inhibitor-amended nitrogen fertilizers. In: O.P. Engelstad (Ed.), Fert. Technol. Use, Madison, WI: SSSA.

11. Shaviv, A. \& Mikkelsen, R.I. (1993). Controlled-release fertilizers to increase efficiency of nutrient use and minimize environmental degradation - a review. Fert. Res., 35, 1-12. DOI: 10.1007/BF00750215.

12. Trenkel, M.E. (2010). Controlled-release and stabilized fertilizers in agriculture, Paris: IFA.

13. Chien, S.H., Prochnow, L.I., Tu, S. \& Snyder, C.S. (2011). Agronomic and environmental aspects of phosphate fertilizers varying in source and solubility: an update review. Nutr. Cycl. Agroecosyst., 89, 229-255. DOI: 10.1007/s10705-010-9390-4.

14. Finck, A. (1992). Fertilizers and their efficient use. In: D.J. Halliday, M.E. Trenkel, W. Wichmann, (Eds.). World Fert. Use Man., Paris: IFA.

15. Shaviv, A. (2000). Advances in controlled release fertilizers. Adv. Agron., 71, 1-49.

16. Górecki, H. (2003). The environmental impact of fertilizer production and use. Przem. Chem., 82(8-9), 833-836.

17. Hofman, G. \& van Cleemput, O. (2004). Nitr. Soil Plant. Paris: IFA.

18. Follett, J.R., Follett, R.F. \& Herz, W.C. (2010). Environmental and human impacts of reactive nitrogen. In: J.A. Delgado, R.F. Follett (Eds.), Adv. Nitr. Managem. Water Qual., Ankeny, IA: SWCS.

19. EEA Raport No7/2005. (2005). Source apportionment of nitrogen and phosphorus inputs into the aquatic environment, Copenhagen: EEA.

20. Townsend, A.R., Howarth, R.W., Bazzaz, F.A., Booth, M.S., Cleveland, C.C., Collinge, S.K., Dobson, A.P., Epstein, P.R., Holland, E.A., Keeney, D.R., Mallin, M.A., Rogers, C.A., Wayne, P. \& Wolfe, A.H. (2003). Human health effects of a changing global nitrogen cycle, Ecol. Environ., 1(5), 240-246. http://dx.doi. org/10.1890/1540-9295(2003)001[0240:HHEOAC]2.0.CO;2

21. Smith, J.E. \& Beutler, E. (1966). Methaemoglobin formation and reduction in man and various animal species. Am. J. Physiol., 210(2), 347-350. 
22. Newbould, P. (1989). The use of nitrogen fertilizer in agriculture. Where do we go practically and ecologically? Plant and Soil. 115, 297-311. DOI: 10.1007/BF02202596.

23. Forman, D. (1989). Are nitrates a significant risk factor in human cancer?, Cancer Surv., 8, 443-458.

24. Freibauer, A. (2003). Regionalised inventory of biogenic greenhouse gas emissions from European agriculture. Eur. $J$. Agron., 19(2), 135-160. DOI: 10.1016/S1161-0301(02)00020-5. 25. Sharpley, A.N. \& Menzel, R.G. (1987). The impact of soil and fertiliser phosphorus on the environment. Adv. Agron., 41, 297-324.

26. Sims, J.T. (1998). Phosphorus soil testing: innovations for water quality protection. Commun. Soil Sci. Plant Anal., 29, 1471-1478. DOI: 10.1080/00103629809370044.

27. Hedley, M. \& McLaughlin, M. (2005). Reactions of phosphate fertilizers and by-products in soils. In: J.T. Sims, A.N. Sharpley (Eds), Phosph.: Agric. Environ., Madison, WI: CSSA, SSSA.

28. Chien, S.H., Prochnow, L.I. \& Cantarella, H. (2009). Recent developments of fertilizer production and use to improve nutrient efficiency and minimize environmental impacts. $A d v$. Agron., 102, 267-322. DOI: 10.1016/S0065-2113(09)01008-6.

29. Mortvedt, J.J. (1987). Cadmium levels in soils and plants from some long-term soil fertility experiments in the United States. J. Environ. Qual., 16, 137-143. DOI:10.2134/ jeq1987.00472425001600020008x.

30. Directive 2000/60/EC of the European Parliament and of the Council. (2000). DzU UE L00.327.

31. Directive 91/676/EWG of the European Parliament. (1991). 32. Matson, P.A., Naylor, R., Ortiz-Monasterio, I. (1998). Integration of environmental, agronomic and economic aspects of fertilizer management. Science 280, 112-115. DOI: 10.1126/ science.280.5360.112.

33. Craswell, E.T. \& Godwin, D.C. (1984). The efficiency of nitrogen fertilizers applied to cereals in different climates. Adv. Plant Nutr., 1, 1-9.

34. Roberts, T.L. (2008). Improving nutrient use efficiency. Turk. J. Agric. For., 32, 177-182.

35. Association of American Plant Food Control Officials (AAPFCO). (1997). Official Publication No. 50, T-29. West Lafayette, IN, USA: AAPFCO.

36. Griessbach, R. \& Eissner, W. (1926). DE Patent No. 431585. Berlin: DPMA.

37. Rohner, L.V. \& Wood, A.P. (1947). US Patent No. 2415705. Washington, D.C.: USPTO.

38. Clapp, J.P. (1991). Properties and uses of liquid ureatriazone-based nitrogen fertilizers Fert. Res. 28, 229-233. DOI: 10.1007/BF01049755.

39. Jahns, T., Ewen, H. \& Kaltwasser, H. (2003). Biodegradability of urea-aldehyde condensation products. J. Polym. Environ. 11(4), 155-159. DOI: 10.1023/A:1026052314695.

40. Koivunen, M.E. \& Horwath, W.R. (2004). Effect of management history and temperature on the mineralization of methylene urea in soil. Nutr. Cycling Agroecosyst. 68(1), 25-35. DOI: 10.1023/B:FRES.0000012232.56756.f0.

41. Alexander, A. \& Helm, H.U. (1990). Ureaform as a slow release fertiliser: A review. J. Plant Nutr. Soil Sci. 153(4), 249-255. DOI: 10.1002/jpln.19901530410.

42. Lunt, O.R. \& Clark, S.B. (1969). Properties and value of 1,1-diureido isobutane (IBDU) as a long-lasting nitrogen fertilizer. J. Agric. Food Chem., 17(6), 1269-1271. DOI: 10.1021/ jf60166a053.

43. Jahns, T. \& Schepp, R. (2001). Isobutylidenediurea degradation by Rhodococcus erythropolis. Biodegradation 12(5), 317-323. DOI: 10.1023/A:1014335602141.

44. Kikushima, T., Hatano, T. \& Takahashi, A. (1970). JP Patent No. 45000874 B4 19700112. Tokyo: JPO.

45. Ushioda, T. (1969). Development and commercial scale of CDU (slow acting fertilizer) technology. Jpn. Chem. $Q$. 5(4), 27-32.
46. Shimizu, T. (1987). Glycoluril as a slow release nitrogen fertilizer. Soil. Sci. Plant Nutr. 33, 291-298. DOI: 10.1080/00380768.1987.10557574.

47. Okuwaki, A. \& Okabe, T. (1991). Development of a new route to oxamide from coal and ammonia, Trends Inorg. Chem. $2,145-158$.

48. Mosdell, D.K., Daniel, W.H. \& Freeborg, R.P. (1987). Melamine and ammeline as nitrogen sources for turfgrasses. Fert. Res. 11(1), 79-86. DOI: 10.1007/BF01049566.

49. Hayase, T. \& Kurihara, J. (1972). JP Patent No. 47006377 B4 19720223. Tokyo: JPO.

50. Hepburn, C., Young, S. \& Arizal, R. (1987). Rubber matrix for the slow release of urea fertilizer. Am. Chem. Soc., Div. Polym. Chem. 28, 94-96.

51. Hepburn, C. \& Arizal, R. (1988). Slow-release fertilizers based on natural rubber. Br. Polym. J. 20(6), 487-491. DOI: $10.1002 /$ pi.4980200605.

52. Hepburn, C. \& Arizal, R. (1989). A controlled-release urea fertilizer. Part 1: The encapsulation of urea fertilizer by rubber: processing and vulcanization procedures, Plast. Rubber Compos. Process. Appl. 12(3), 129-134.

53. Hepburn, C. \& Arizal, R. (1989). A controlled-release urea fertilizer. Part 2: Preparation of the rubber-urea matrix and the split-feeding mixing technique. Plast. Rubber Compos. Process. Appl. 12(3), 135-140.

54. Hepburn, C., Young, S. \& Arizal, R. (1989). A controlledrelease urea fertilizer. Part 3: Soil leaching and growth trials Plast. Rubber Compos. Process. Appl. 12(3), 141-146.

55. Hassan, Z.A., Young, S.D., Hepburn, C. \& Arizal, R. (1990). An evaluation of urea-rubber matrices as slow-release fertilizers. Fert. Res. 22, 63-70. DOI: 10.1007/BF01116180.

56. Abdel Bary, E.M., El-Shekeil, A.G., Helaly, F.M., Sarhan, A.A. \& Abdel Razik, H.H. (1992). Sustained-release natural rubber formulations for urea. Plast. Rubber Compos. Process. Appl. 17(2), 99-107.

57. Helaly, F.M. \& Abo-Elela, S.I. (1990). Protection of surface water from eutrophication via controlled release of phosphate fertilizer. J. Control. Rel., 12(1), 39-44. DOI: 10.1016/01683659(90)90181-R.

58. Helaly, F.M., Abdel-Bary, E.M., Sarhan, A.A. \& AbdelRazik, H.H. (1993). Minimization of water pollution and environmental problems via controlled-release styrene-butadiene rubber formulations containing ammonium nitrate. Plast. Rubber Compos. Process. Appl. 19(2), 111-115.

59. Helaly, F.M. \& Nashar, D.E. (2002). Slow-release rubber formulations containing $\mathrm{ZnSO}_{4}$. Polym. Test. 21(8), 867-875. 60. Abd El-Kader, A.A. \& Attia, M. (2006). Nutrients release and biological aspects of butadiene styrene - fertilizer mixtures. Egypt. J. Soil Sci. 46(1), 69-77.

61. Joyce, D.C., Bell, L.C., Asher, C.J. \& Edwards, D.G. (1988). Thermoplastic matrix controlled-release zinc fertilizers. I. Laboratory characterization. Fert. Res. 17(3), 235-250. DOI: 10.1007/BF01049580.

62. Joyce, D.C., Bell, L.C., Edwards, D.G. \& Asher, C.J. (1988). Thermoplastic matrix controlled-release zinc fertilizers. II. Effect of soil and formulation characteristics on zinc emission. Fert. Res. 17(3), 251-266. DOI: 10.1007/BF01049581.

63. Joyce, D.C., Asher, C.J., Edwards, D.G. \& Bell, L.C. (1988). Thermoplastic matrix controlled-release zinc fertilizers. III. Zinc nutrition of linseed on a sand and a clay. Fert. Res. 17(3), 267-283. DOI: 10.1007/BF01049582.

64. Perez, M.G., Rueda, J.I.P, Mateos, F.B. \& Marin, J.P. (1999). Slow-release fertilizer in the form of emulsion. Chem. Biochem. Eng. Q. 13(1), 21-26.

65. Lunt, O.R., Kofranek, A.M. \& Clark, S.B. (1964). Availability of minerals from magnesium ammonium phosphates $J$. Agric. Food Chem. 12(6), 497-504. DOI: 10.1021/jf60136a005. 66. de-Bashan, L.E. \& Bashan, Y. (2004). Recent advances in removing phosphorus from wastewater and its future use 
as fertilizer. Water Res. 38, 4222-4246. DOI:10.1016/j.watres.2004.07.014.

67. Grzmil, B. \& Wronkowski, J. (2004). Processes for removing and recovering phosphates from wastewaters. Chem. Rev. 83(6), 275-280.

68. Matynia, A., Hutnik, N., Piotrowski, K., Wierzbowska, B. \& Koralewska, J. (2009). Recovery of phosphate ions by continuous precipitation and crystallization of struvite in DTM type crystallizer with jet pump. Progr. Environ. Sci. Technol. 2, 986-993.

69. Rahman, M.M., Salleh, M.A.M., Rashid, U., Ahsan, A., Hossain, M.M. \& Ra, C.S. (2014). Production of slow release crystal fertilizer from wastewaters through struvite crystallization - A review. Arab. J. Chem. 7, 139-155. DOI: 10.1016/j. arabjc.2013.10.007.

70. Solihin, Zhang, Q., Tongamp, W. \& Saito, F. (2010). Mechanochemical route for synthesizing $\mathrm{KMgPO}_{4}$ and $\mathrm{NH}_{4} \mathrm{MgPO}_{4}$ for application as slow-release fertilizers. Ind. Eng. Chem. Res. 49(5), 2213-2216. DOI: 10.1021/ie901780v.

71. Tongamp, W., Zhang, Q. \& Saito, F. (2008). Mechanochemical route for synthesizing nitrate form of layered double hydroxide. Powder Technol. 185(1), 43-48. DOI: 10.1016/j. powtec.2007.09.013.

72. Zhang, Q., Solihin \& Saito, F. (2009). Mechanochemical synthesis of slow-release fertilizers through incorporation of alumina composition into potassium/ammonium phosphates. J. Amer. Ceram. Soc. 92(12), 3070-3073. DOI: 10.1111/j.1551-2916.2009.03291.X.

73. Solihin, Zhang, Q., Tongamp, W. \& Saito, F. (2010). Mechanochemical synthesis of kaolin- $\mathrm{KH}_{2} \mathrm{PO}_{4}$ and kaolin- $\mathrm{NH}_{4} \mathrm{H}_{2} \mathrm{PO}_{4}$ complexes for application as slow release fertilizer. Powder Technol. 212(2), 354-358. DOI: 10.1016/j.powtec.2011.06.012. 74. Yuan, W., Solihin, Zhang, Q., Kano, J. \& Saito, F. (2014). Mechanochemical formation of $\mathrm{K}-\mathrm{Si}-\mathrm{Ca}-\mathrm{O}$ compound as a slow-release fertilizer. Powder Technol. 260, 22-26. http:// dx.doi.org/10.1016/j.powtec.2014.03.072

75. Bolan, N.S., Hedley, M.J. \& Loganathan, P. (1993). Preparation, forms and properties of controlled-release phosphate fertilizers. Fert. Res. 35, 13-24. DOI: 10.1007/BF00750216.

76. Rajan, S.S.S., Watkinson, J.H. \& Sinclair, A.G. (1996). Phosphate rock for direct application to soils. Adv. Agron. 57, 77-159. DOI: 10.1016/S0065-2113(08)60923-2.

77. Skut, J., Hoffmann, J., Hoffmann, K. (2011). Evaluation of the progress of sulfuric acid acidulation of phosphate rocks. Przem. Chem. 90(5), 1024-1028.

78. Skut, J., Hoffmann, J. \& Hoffmann, K. (2012). Temperature and moisture influence on the curing process of PAPR type fertilizer products. Pol. J. Chem. Technol. 14(3), 77-82. DOI: 10.2748/v10026-012-0106-1.

79. Ando, J. (1987). Thermal phosphates. In: F.T. Nielsson (Ed.), Man. Fert. Proces. New York: Marcel Dekker Inc.

80. Ranawat, P., Kumar, K.M. \& Sharma, N.K. (2009). A process for making slow-release phosphate fertilizer from low-grade rock phosphate and siliceous tailings by fusion with serpentinite. Curr. Sci. 96(6), 843-848.

81. Guimond, R.J. \& Hardin, J.M. (1989). Radioactivity released from phosphate-containing fertilizers and from gypsum. Int. J. Radiat. Appl. Instrum. Part C, 34(2), 309-315. DOI: 10.1016/1359-0197(89)90238-5.

82. Scholten, L.C. \& Timmermans, C.W.M. (1996). Natural radioactivity in phosphate fertilizers. Fert. Res. 43, 103-107. DOI: $10.1007 / \mathrm{BF} 00747688$.

83. Ioannides, K.G., Mertzimekis, T.J., Papachristodoulou, C.A. \& Tzialla, C.E. (1997). Measurements of natural radioactivity in phosphate fertilizers. Sci. Total Environ. 196(1), 63-67. DOI: 10.1016/S0048-9697(96)05390-9.

84. Roselli, C., Desideri, D. \& Meli, M.A. (2009). Radiological characterization of phosphate fertilizers: Comparison between alpha and gamma spectrometry. Microchem. J. 91(2), 181-186. DOI: $10.1016 /$ j.microc.2008.10.003.
85. Wacławska, I. \& Szumera, M. (2003), Thermal analysis of glasses for proecological applications. J. Thermal Anal. Calorim. 72(3), 1065-1072.

86. Wacławska, I. \& Szumera, M. (2009). Reactivity of silicate-phosphate glasses in soil environment. J. Alloys Compd. 468(1-2), 246-253. DOI: 10.1023/A:1025059424522

87. Sułowska, J., Wacławska, I. \& Olejniczak, Z. (2013). Structural studies of copper-containing multicomponent glasses from the $\mathrm{SiO}_{2}-\mathrm{P}_{2} \mathrm{O}_{5}-\mathrm{K}_{2} \mathrm{O}-\mathrm{CaO}-\mathrm{MgO}$ system. Vib. Spectrosc. 65, 44-49. http://dx.doi.org/10.1016/j.vibspec.2012.11.013

88. Sułowska, J., Wacławska, I. \& Olejniczak, Z. (2014). Effect of glass composition on the interactions between structural elements in Cu-containing silicate-phosphate glasses. J. Thermal Anal. Calorim. 116(1), 51-59. DOI: 10.1007/s10973-014-3705-7. 89. Mandlule, A., Doehler, F., van Wuellen, L., Kasuga, T. \& Brauer, D.S. (2014). Changes in structure and thermal properties with phosphate content of ternary calcium sodium phosphate glasses. J. Non-Cryst. Solids 392-393, 31-38. DOI: 10.1016/j.jnoncrysol.2014.04.002.

90. Qiu, Q. \& Hlavacek, V. (2010). Energy estimation on CRN process of fly ash as a slow-release nitrogen fertilizer. Ind. Eng. Chem. Res. 49(12), 5939-5944. DOI: 10.1021/ie100391y. 91. Virkar, A.N., Misra, S.N., Sharma, N., Ray, H.S. \& Paul, A. (1987). Thermal analysis and x-ray diffraction studies on controlled release fertilizers prepared by incorporating nutrients into blast furnace slag. Thermochim. Acta 111, 135-142. DOI: 10.1016/0040-6031(87)88042-5.

92. Yao, Y., Hamada, E., Sato, K., Akiyama, T. \& Yoneyama, T. (2014). Identification of the major constituents of fused potassium silicate fertilizer. ISIJ Int. 54(4), 990-993. DOI: http://dx.doi.org/10.2355/isijinternational.54.990.

93. Ming, D.W. \& Allen, E.R. (2001). Use of natural zeolites in agronomy, horticulture, and environmental soil remediation. Rev. Mineral. Geochem. 45, 619-654. DOI: 10.2138/ rmg.2001.45.18.

94. Pereira, E.I., Minussi, F.B., da Cruz, C.C.T., Bernardi, A.C.C. \& Ribeiro, C. (2012). Urea-montmorillonite-extruded nanocomposites: a novel slow-release material. J. Agric. Food Chem. 60(21), 5267-5272. DOI: 10.1021/jp507826j.

95. Ray, S.K., Varadachari, Ch. \& Ghosh, K. (1993). Novel slow-releasing micronutrient fertilizers. 1. Zinc compounds. Ind. Eng. Chem. Res. 32(6), 1218-1227. DOI: 10.1021/ie00018a030. 96. Ray, S.K., Varadachari, Ch. \& Ghosh, K. (1997). Novel slow-releasing micronutrient fertilizers. 2. Copper compounds. J. Agric. Food Chem. 45(4), 1447-1453. DOI: 10.1021/jf960499. 97. Bhattacharya, I., Bandyopadhyay, S., Varadachari, Ch. \& Ghosh, K. (2007). Development of a novel slow-releasing ironmanganese fertilizer compound. Ind. Eng. Chem. Res. 46(9), 2870-2876. DOI: 10.1021/ie060787n.

98. Bhattacharya, I., Bandyopadhyay, S., Ghosh, K. \& Varadachari, Ch. (2008). New slow-releasing molybdenum fertilizer. J. Agric. Food Chem. 56(4), 1343-1349. DOI: 10.1021/jf072878g. 99. Chandra, P.K., Ghosh, K. \& Varadachari, Ch. (2009). A new slow-releasing iron fertilizer. Chem. Eng. J. 155(1-2), 451-456. DOI: 10.1016/j.cej.2009.07.017.

100. Grzmil, B.U. \& Kic, B. (1995). Potassium, sodium and calcium polyphosphates with controlled solubility. J. Agric. Food Chem. 43(9), 2463-2470. DOI: 10.1021/jf00057a028. 